\title{
Expression profile of MODY3/HNF-1 $\alpha$ protein in the developing mouse pancreas
}

\author{
T. Nammo ${ }^{1}$, K. Yamagata ${ }^{1}$, R. Hamaoka ${ }^{1}$, Q. Zhu ${ }^{1}$, T. E. Akiyama ${ }^{2}$, F. J. Gonzalez ${ }^{2}$ J. Miyagawa ${ }^{1}$, \\ Y. Matsuzawa ${ }^{1}$ \\ ${ }^{1}$ Department of Internal Medicine and Molecular Science, Graduate School of Medicine, Osaka University, Osaka, Japan \\ ${ }^{2}$ Laboratory of Metabolism, National Cancer Institute, National Institutes of Health, Bethesda, Maryland, USA
}

\section{Abstract}

Aims/hypothesis. One subtype of MODY (MODY3) results from the heterozygous mutation of a hepatocyte nuclear factor (HNF)-1 $\alpha$. The pattern of HNF-1 $\alpha$ expression in the normal pancreas has not been determined. This study aimed to clarify the profile of HNF-1 $\alpha$ protein expression in the developing mouse pancreas.

Methods. Double immunofluorescence staining was carried out for HNF-1 $\alpha$ and pancreatic hormones or transcription factors (PDX-1, Pax6, Is11, and Nkx2.2). The expression of these transcription factors was also studied in the beta cells of $H N F-1 \alpha$ mutant mice.

Results. HNF-1 $\alpha$ was expressed by both endocrine and exocrine cells of the pancreas. Double immunofluorescence staining showed that HNF-1 $\alpha$ was expressed in the nuclei of alpha cells, beta cells, delta cells, and pancreatic polypeptide (PP) cells. HNF-1 $\alpha$ was first detected in most pancreatic epithelial cells on embryonic day
10.5 (E10.5), and hormone-positive endocrine cells and amylase-positive cells expressed HNF-1 $\alpha$ on E15.5. Most of the Pax6-, Isl1-, or PDX-1-positive cells showed co-expression of HNF-1 $\alpha$. However, HNF- $1 \alpha$ immunoreactivity was not observed in $36.0 \%$ of Nkx2.2-positive cells. Expression of Nkx2.2, Isl1 and Pax6 seemed to be normal in the beta cells of transgenic mice with dominant negative overexpression of HNF-1 $\alpha$. Expression of PDX-1 did not change in the beta cells of pre-diabetic $H N F-1 \alpha(-l-)$ mice, but expression was markedly decreased in the diabetic stage. Conclusion/interpretation. HNF-1 $\alpha$ is expressed by both endocrine cells and exocrine cells of the pancreas from the foetal stage along with other transcription factors, so HNF- $1 \alpha$ might play a role during development. [Diabetologia (2002) 45:1142-1153]

Keywords HNF- $1 \alpha$, transcription factor, development, mouse pancreas.
Hepatocyte nuclear factor- $1 \alpha$ (HNF-1 $\alpha$ ) is a homeodomain-containing transcription factor that regulates the expression of a large number of liver-specific genes $[1,2]$. HNF-1 $\alpha$ protein is highly conserved among mammals and is composed of three functional

Received: 8 February 2002 / Revised: 30 April 2002

Published online: 28 June 2002

(C) Springer-Verlag 2002

Corresponding author: K. Yamagata, MD, Department of Internal Medicine and Molecular Science, Graduate School of Medicine, B5, Osaka University, 2-2 Yamada-oka, Suita, Osaka 565-0871, Japan, E-mail: kazu@imed2.med.osaka-u.ac.jp Abbreviations: HNF, Hepatocyte nuclear factor; PDX, pancreatic duodenal homeobox; Pax, paired-box; Isl, islet. domains: an amino-terminal dimerisation domain, a DNA-binding domain with homeodomain-like and POU-like motifs, and a $\mathrm{COOH}$-terminal transactivation domain. Although HNF-1 $\alpha$ was initially identified as a hepatocyte-specific transcription factor, it is known also to be expressed in the pancreas $[3,4,5,6]$. We have found that heterozygous mutations of the $H N F-1 \alpha$ gene cause a form of maturity-onset diabetes of the young (MODY3) [7] and clinical studies have shown that MODY3 is characterized by impaired insulin secretion $[8,9]$, suggesting an important role of HNF- $1 \alpha$ in pancreatic beta cells. Because the pancreas is composed of four kinds of endocrine cells as well as exocrine cells, we need to determine which cells in the pancreas express HNF-1 $\alpha$. The MODY3 phenotype suggests that HNF-1 $\alpha$ should be expressed by pancre- 
atic beta cells. It has already been reported that HNF-1 $\alpha$ expression can be detected in insulinoma cells $[10,11]$ but the exact cells expressing HNF-1 $\alpha$ in the normal pancreas have not been determined. In addition, it is not known whether HNF-1 $\alpha$ is expressed in the developing pancreas. A number of transcription factors are initially expressed during embryogenesis and these factors control the differentiation of pancreatic endocrine and exocrine cells [12, 13, 14]. Although HNF-1 $\alpha$ is involved in insulin secretion $[15,16,17,18,19]$, it might have an additional role during the development of the pancreas. Thirdly, a cascade of transcription factors controls the development of pancreatic beta cells [14, 20, 21]. Earlier studies have shown neurogenin-3 and Nkx2.2 are expressed in endocrine cells in the early stage, while Isl1 and Pax6 are expressed by relatively mature endocrine cells $[20,21,22,23,24,25,26]$. If HNF- $1 \alpha$ is expressed in the developing pancreas, what is its position in the developmental transcription cascade? In this study, we investigated the expression of MODY3/ HNF-1 $\alpha$ protein during pancreatic development.

\section{Materials and methods}

Transfection and western blot analysis. Eight micrograms of pcDNA3.1-HNF-1 $\alpha$ or empty pcDNA3.1 expression plasmid was transfected into COS-7 cells with Lipofectamine plus reagent (Life Technologies, Tokyo, Japan). Nuclear proteins were extracted $48 \mathrm{~h}$ after transfection [27]. Nuclear proteins of mouse hepatocytes were extracted as described previously [28]. COS-7 protein $(20 \mu \mathrm{g})$ or hepatocyte protein $(40 \mu \mathrm{g})$ was subjected to $10 \%$ SDS-polyacrylamide gel electrophoresis and transferred by electroblotting to an Immobilon-P membrane (Millipore, Bedford, Mass., USA). The membrane was incubated with goat polyclonal anti-HNF-1 $\alpha$ antibody (N-19, Santa Cruz, Calif., USA) for $12 \mathrm{~h}$ at $4^{\circ} \mathrm{C}$ and then was incubated further with horseradish peroxidase (HRP)-conjugated anti-goat IgG antibody. Bands were visualised with ECL western blotting detection reagents (Amersham Pharmacia Biotech, Buckinghamshire, UK). To test the specificity of the anti-HNF-1 $\alpha$ antibody, it was incubated with an excess of HNF-1 $\alpha$ peptide (VSKLSQLOTELLAALLESGC) (Santa Cruz), which was the peptide used for the immunisation. Western blot analysis was also done using the antibody after absorption.

Animals and sample preparation. Under general anesthesia, ten-week-old C57BL/6J Jcl mice were perfused with $4 \%$ paraformaldehyde (PFA) in $0.1 \mathrm{~mol} / \mathrm{l}$ phosphate buffer (PB). After isolation, the liver, kidney, heart, brain, and pancreas were fixed in the solution for $6 \mathrm{~h}$. Pregnant C57BL/6J Jcl mice were purchased from Clea Japan (Tokyo, Japan). The morning when the vaginal plug was detected was designated as embryonic day 0.5 (E0.5). Embryos were harvested from E9.5 to E18.5. The pancreas of each embryo was fixed in $4 \% \mathrm{PFA} / 0.1 \mathrm{~mol} / \mathrm{l}$ PB for $6 \mathrm{~h}$, followed by cryoprotection in serial sucrose solutions $(5-30 \%)$ at $4{ }^{\circ} \mathrm{C}$ and freezing for storage. Consecutive sections (6 $\mu \mathrm{m}$ thick) were cut and collected on glass slides for examination. Transgenic mice with a dominant negative overexpression of mutant human HNF-1 $\alpha$ (P291fsinsC-HNF-1 $\alpha$ ) in beta cells and HNF-1 $\alpha$ null mice have been described [16, $18,19]$. The experimental protocol was approved by the Ethics

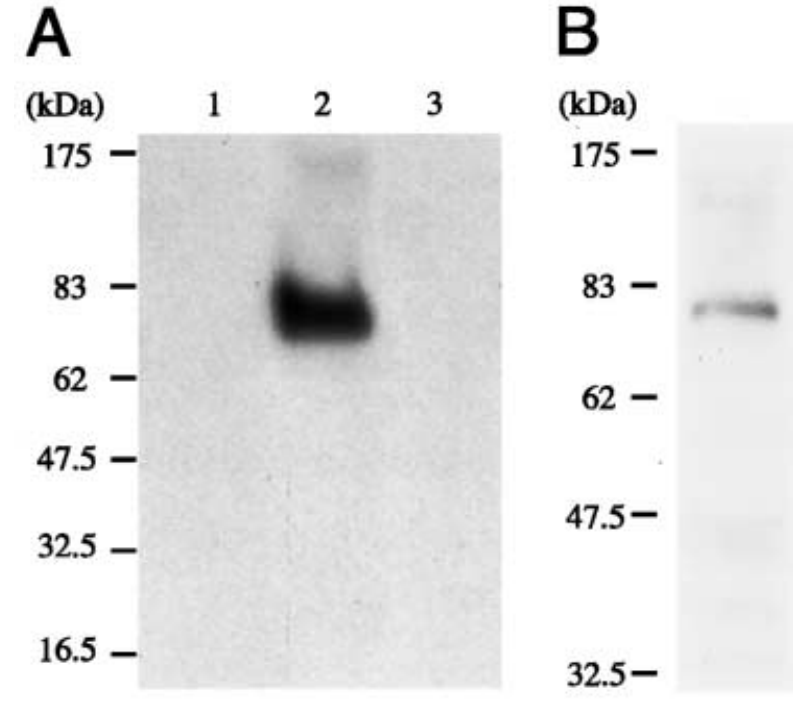

Fig. 1A, B. Anti-HNF-1 $\alpha$ antibody specifically recognizes HNF-1 $\alpha$ protein. A Twenty $\mu \mathrm{g}$ of nuclear proteins from COS-7 cells (lane 1) or COS-7 cells transfected with pcDNA3.1-HNF$1 \alpha$. (lanes 2 and 3 ) were probed with a goat polyclonal antibody directed against human HNF-1 $\alpha$. HNF-1 $\alpha$ antibody was incubated with synthetic HNF-1 $\alpha$ polypeptide and used for western blot analysis (lane 3). B Nuclear protein from mouse hepatocytes $(40 \mu \mathrm{g})$ was subjected to western blot analysis using the antibody

Review Committee for Animal Experimentation of Osaka University.

Immunohistochemistry. The primary antibodies for this study were used at the following dilutions: guinea pig anti-porcine insulin (DAKO, Carpinteria, Calif., USA) 1:500; rabbit antihuman glucagon (Linco, St. Louis, Mo., USA) 1:200; rabbit anti-human $\alpha$-amylase (Sigma, St. Louis, Mo., USA) 1:200; rabbit anti-human somatostatin (DAKO) 1:200; rabbit antihuman PP (DAKO) 1:500; goat anti-HNF-1 $\alpha$ (N-19, Santa Cruz) 1:100; mouse monoclonal anti-Pax6 (Developmental Studies Hybridoma Bank, Iowa city, Iowa, USA) 1:20; mouse monoclonal anti-Isl1 (Developmental Studies Hybridoma Bank) 1:20; mouse monoclonal anti-Nkx2.2 (Developmental Studies Hybridoma Bank) 1:20; and rabbit anti-mouse PDX-1 [29] 1:500. The fluorescent-labelled secondary antibodies were as follows: Alexa Fluor 594-conjugated goat anti-mouse, antirabbit, or anti-guinea pig antibodies (1:200) (Molecular Probes, Eugene, Ore., USA), Alexa Flour 488-conjugated goat anti-guinea pig antibody (1:200) (Molecular Probes), and rhodamine-conjugated goat anti-guinea pig antibody (1:200) (Chemicon, Temecula, Calif., USA). The HNF-1 $\alpha$ signal was amplified by applying biotinylated donkey anti-goat antibody (Chemicon). Biotinylated secondary antibodies were detected with Alexa Flour 488-conjugated streptavidin (Molecular Probes) or the $\mathrm{ABC}$ Elite immunoperoxidase system (Vector, Burlingame, Calif., USA). Peroxidase activity was detected with a Liquid DAB Substrate Kit (Zymed, South San Francisco, Calif., USA) or a VIP Substrate Kit (Vector). A goat antimouse IgG Fab fragment (1:5 Jackson ImmunoResearch Laboratories, West Grove, Penn., USA) or a Histomouse-Plus Kit (Zymed) was used to block non-specific staining by endogenous mouse immunoglobulins. Samples were viewed under a light microscope (PROVIS AX80T, Olympus, Tokyo, Japan) or a confocal microscope (LSM510, Zeiss, Jena, West Germany). 


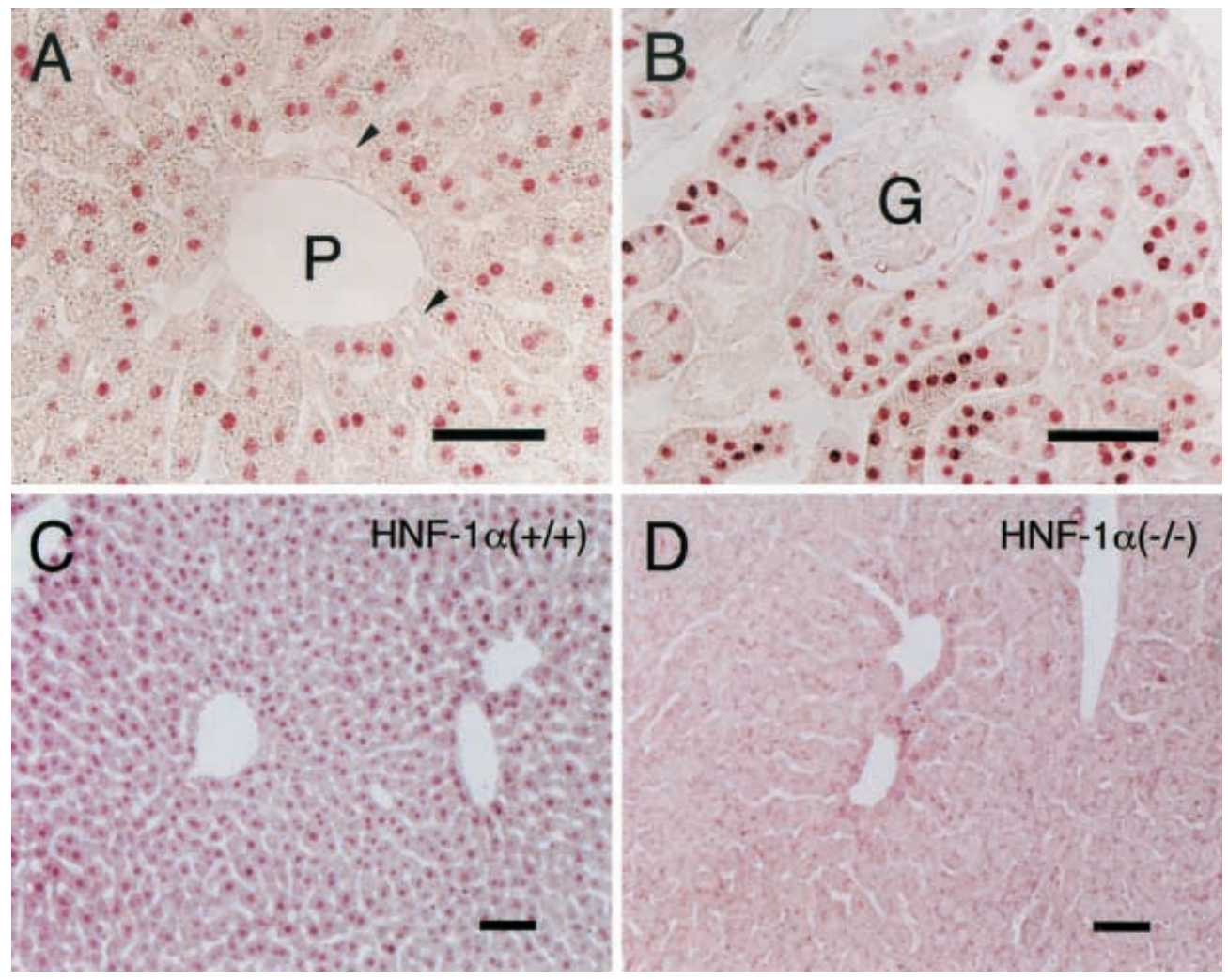

Fig. 2A-D. Pattern of HNF-1 $\alpha$ expression in adult mice. The liver (A) and kidney (B) of 10-week-old C57BL/6J mice were immunostained with HNF-1 $\alpha$ antibody (VIP label, purple). Arrowheads indicate bile ducts. P: portal vein. G: glomerulus. C, D There was no nuclear staining of hepatocytes from 2-week-old $H N F$ - $1 \alpha(-/-)$ mice (Bar=40 $\mu \mathrm{m})$

Cell counting. Three sections cut at $60 \mu \mathrm{m}$ intervals from each E15.5 pancreas were double stained for HNF-1 $\alpha$ and transcription factors (PDX-1, Is11, Pax6, and Nkx2.2). Then, the number of cells co-expressing HNF-1 $\alpha$ and other transcription factors was counted.

\section{Results}

Detection of $H N F-1 \alpha$ protein by western blot analysis. COS-7 cells, which do not possess endogenous HNF-1 $\alpha$, were transfected with the HNF- $1 \alpha$ expression plasmid, when western blot analysis was done with a polyclonal HNF-1 $\alpha$ antibody (Fig. 1A), a single band corresponding to $\mathrm{HNF}-1 \alpha$ protein $(73 \mathrm{kDa})$ was detected. This band was lost after pre-incubation of the antibody with an excess of the HNF-1 $\alpha$ peptide used for immunisation, suggesting that the antibody specifically recognized HNF-1 $\alpha$ protein. This antibody could detect endogenous HNF-1 $\alpha$ in mouse hepatocytes (Fig. 1B).

Expression of $H N F-1 \alpha$ protein in adult mouse tissues. HNF-1 $\alpha$ immunoreactivity was detected in he- patocyte nuclei and in the proximal tubules of the kidney in adult mice. In contrast, no immunoreactivity was detected in the bile duct or the glomeruli of the kidney (Fig. 2A, B). HNF-1 $\alpha$ staining was also detected in the stomach and intestine, but was not detected in the brain and heart. This restricted pattern of HNF-1 $\alpha$ staining was compatible with the reported tissue distribution of HNF-1 $\alpha$ mRNA $[3,4,5,30,31]$ and $\beta$-galactosidase expression of $H N F-1 \alpha(+/-)$ mice [6]. Furthermore, HNF-1 $\alpha$ immunoreactivity was absent from the nuclei of hepatocytes in $H N F-1 \alpha(-/-)$ mice (Fig. 2C, D). These data suggested that this antibody could correctly recognize HNF-1 $\alpha$. Next, we tested the pancreatic expression of HNF-1 $\alpha$ using the antibody. As a result, HNF-1 $\alpha$ protein was detected in both endocrine and exocrine cells. Double immunofluorescent staining for HNF-1 $\alpha$ and endocrine hormones showed that HNF-1 $\alpha$ was expressed in the nuclei of glucagon-positive alpha cells, insulin-positive beta cells, somatostatin-positive delta cells, and pancreatic polypeptide (PP) cells (Fig. 3). However, HNF-1 $\alpha$ staining was not found in the nuclei of the pancreatic duct cells.

Time course of pancreatic HNF-1 $\alpha$ expression in the developing mouse. RT-PCR analysis showed HNF-1 $\alpha$ mRNA is expressed in the mouse pancreas at E15.5. To assess the pattern of HNF-1 $\alpha$ expression in the embryonic pancreas more precisely, immunohistochemical analysis was done at different times. HNF-1 $\alpha$ expression could hardly be detected in the pancreas at E9.5. 

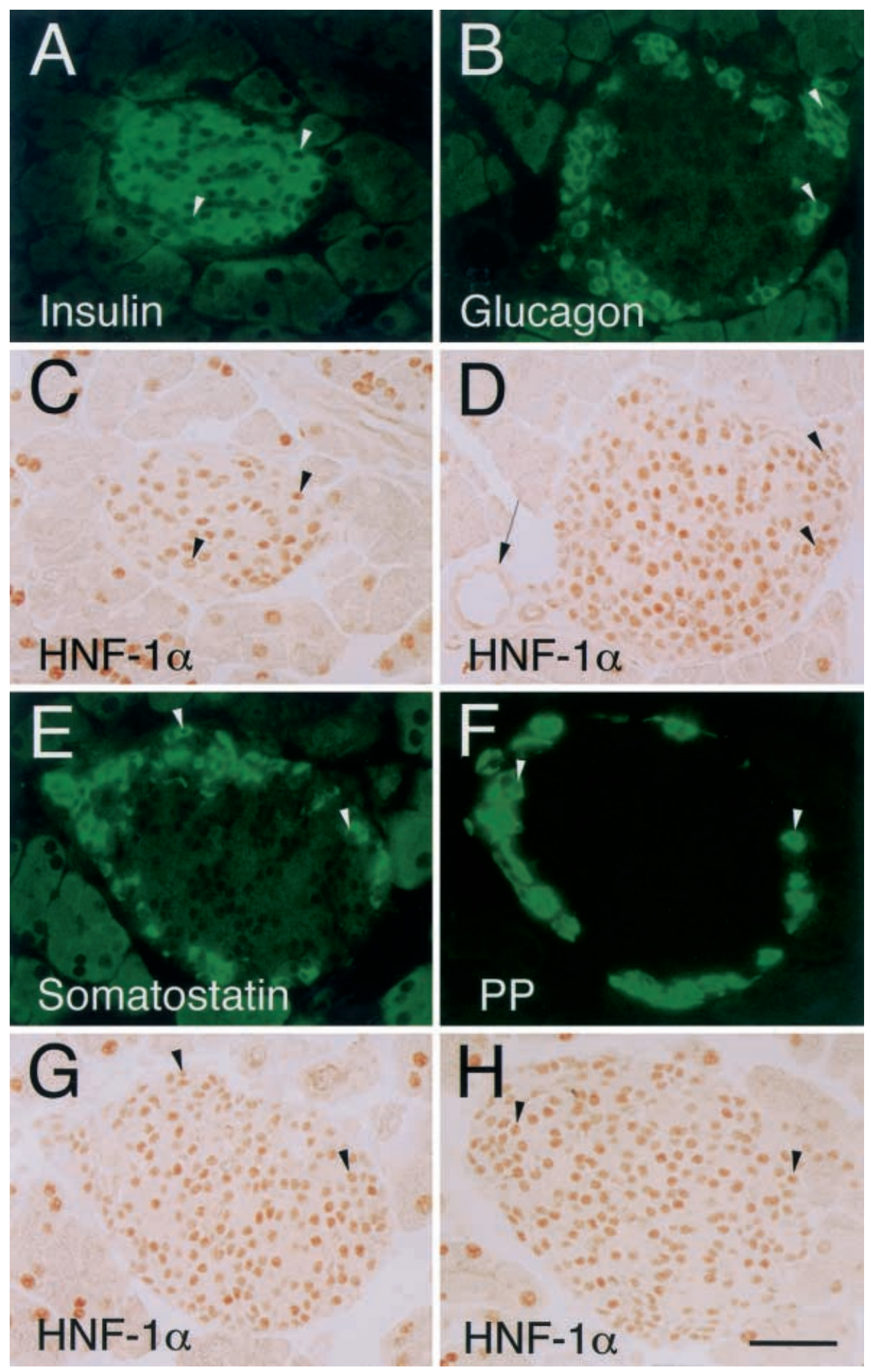

Fig. 3A-H. Expression of HNF-1 $\alpha$ in the adult mouse pancreas. Double immunostaining for pancreatic hormones [insulin: (A), glucagon: (B), somatostatin: (E), and PP: (F)] (Alexa 488 label, green) and HNF-1 $\alpha(\mathbf{C}, \mathbf{D}, \mathbf{G}, \mathbf{H})(\mathrm{DAB}$ label, brown) was done using an adult mouse pancreas (10-week old, male). Arrows indicate representative hormone-positive cells coexpressing HNF-1 $\alpha$. Expression of HNF-1 $\alpha$ was negative in pancreatic duct cells (arrowhead) (Bar=40 $\mu \mathrm{m})$

However, HNF-1 $\alpha$ was found in most epithelial cells on day E10.5, and staining was more intense by E11.5 (Fig. 4). During the second transition (from stage E13.0 [32]), the duct termini differentiate into exocrine cells and the endocrine cells start to form clusters. The duct epithelium formed branching structures around E13.5 and cells with a relatively high intensity of HNF-1 $\alpha$ staining were detected at the periphery of the duct epithelium or adjacent to it (Fig. 4E). At E15.5-16.5, 

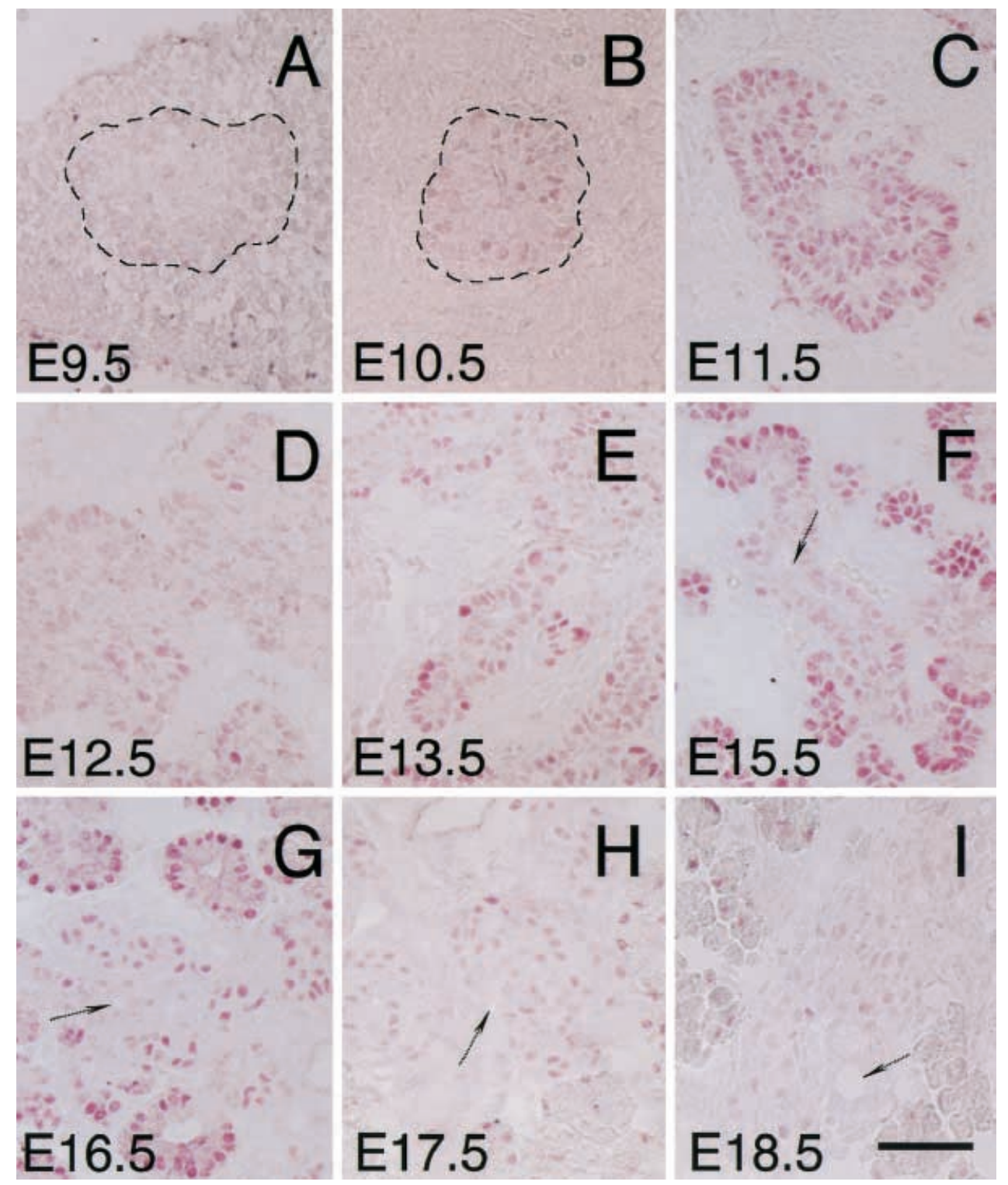

Fig. 4A-I. Changes in the pattern of HNF-1 $\alpha$ expression in the developing mouse pancreas. Immunohistochemical staining of the embryonic pancreas for HNF-1 $\alpha$ (VIP label, purple). The area of the pancreatic bud (A, B: broken lines) was determined by staining for $\mathrm{Nkx} 2.2$ in the serial section. HNF-1 $\alpha$ staining was first detected at E10.5. Acinar cells and islet cells expressed HNF-1 $\alpha$, while duct cells showed little expression. Arrows indicate the duct lumen $($ Bar $=40 \mu \mathrm{m})$

strong HNF-1 $\alpha$ staining was observed in differentiated acinar cells with a polarised appearance but HNF-1 $\alpha$ expression was weak in the duct epithelium. Nuclear staining for HNF-1 $\alpha$ showed a decrease of intensity on E17.5 but HNF-1 $\alpha$ staining was still found in acinar cells and mature islet cells. The pattern of expression was similar on E18.5, which was one day prior to birth.

In 10 -week-old mice, HNF-1 $\alpha$ was expressed by alpha cells, beta cells, delta cells, and PP cells (Fig. 3). We also examined the types of HNF-1 $\alpha$-posi- tive cells in the developing pancreas. On E15.5, HNF$1 \alpha$ was expressed in alpha cells, beta cells, and delta cells (Fig. 5). Expression of HNF-1 $\alpha$ in PP cells could not be tested because PP cells had not appeared at this stage [33]. Double staining for amylase and HNF-1 $\alpha$ indicated that HNF-1 $\alpha$ was also expressed by amylase-positive exocrine cells.

Position of HNF-1 $\alpha$ in the sequence of transcription factor expression. To understand the position of HNF- $1 \alpha$ in the sequence of transcription factor expression, we did double staining of E15.5 pancreases for HNF-1 $\alpha$ and various transcription factors (PDX-1, Pax6, Isl1, and Nkx2.2) (Fig. 6). PDX-1 is a homeodomain-containing transcription factor [34], and its pancreatic targeted disruption results in the failure of pancreatic development in mice [35]. Pax6 is a transcription factor containing a paired box and homeodomain, and is an essential determinant of the fate of endocrine cells [26]. Isl1 is a member of the LIM ho- 

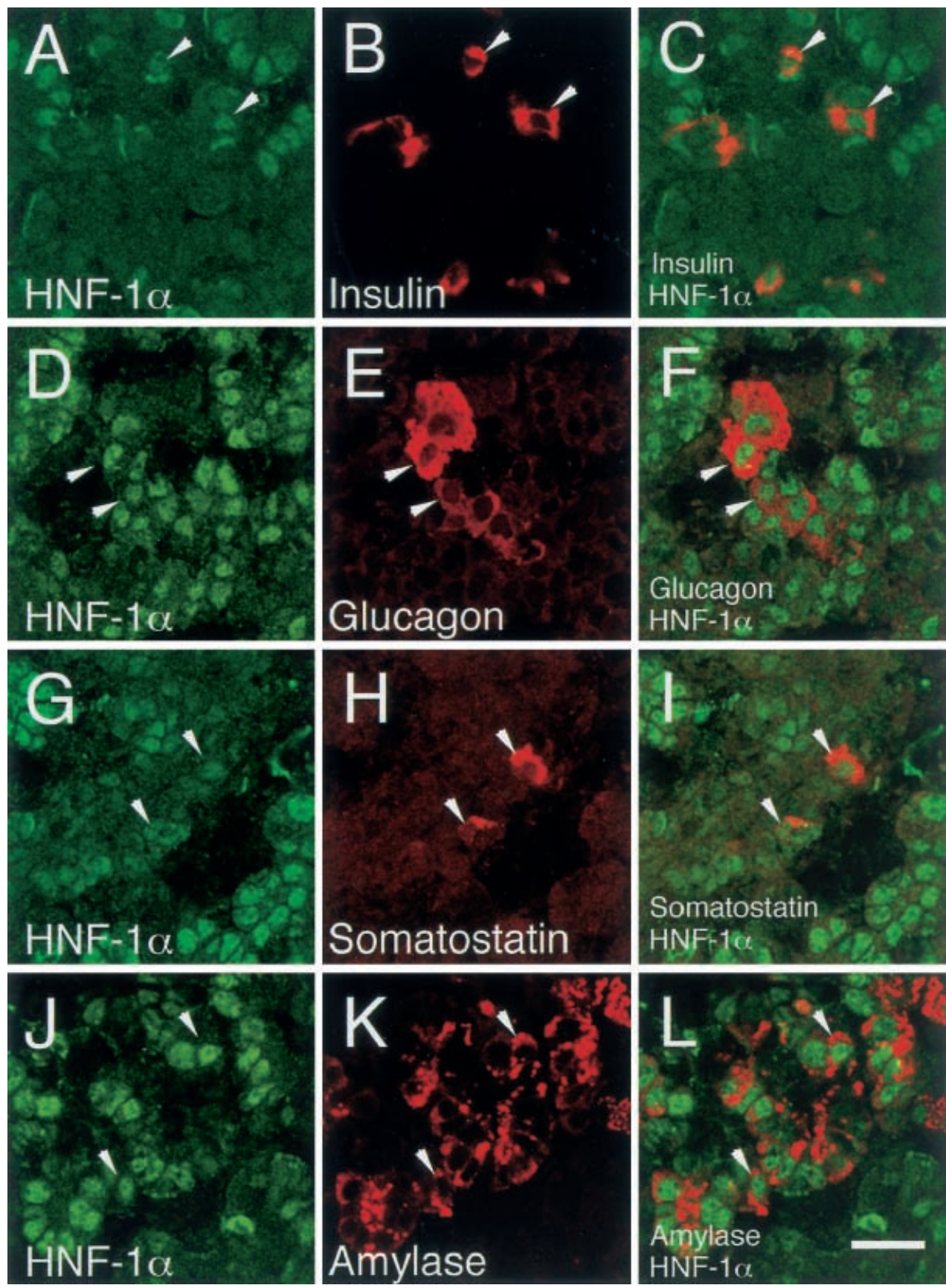

Fig. 5A-L. Expression of HNF-1 $\alpha$ by differentiated pancreatic exocrine and endocrine cells during development. Double immunofluorescent staining for pancreatic hormones (glucagon, insulin, and somatostatin) or amylase (Alexa 594 label, red) and HNF-1 $\alpha$ (Alexa 488, green) at E15.5. C, F, I, and L are superimposed images. Arrowheads indicate representative cells co-expressing HNF-1 $\alpha($ Bar=20 $\mu \mathrm{m})$

meodomain transcription factor family. Isl1 null mice show early blocking of the differentiation of endocrine cells in the pancreas $[22,36]$. Nkx2.2 contains an NKhomeodomain and its expression can be detected in alpha, beta, and PP cells, but not in delta cells or exo- crine cells [37]. It has been reported that 70 to $80 \%$ of Nkx2.2-positive cells co-express a proendocrine marker, ngn3 [25]. We found that most PDX-1-positive (98.0\%) and Pax6-positive cells $(98.0 \%)$ co-expressed HNF-1 $\alpha$, although a few PDX-1+/HNF- $1 \alpha^{-}$or Pax6 ${ }^{+} / \mathrm{HNF}-1 \alpha^{-}$cells were still observed. $10.1 \%$ of Isl1-positive cells were negative for HNF-1 $\alpha$ expression. In contrast, $\mathrm{Nkx} 2.2^{+} / \mathrm{HNF}-1 \alpha^{-}$cells were readily detected and only $64.0 \%$ of the Nkx 2.2 cells showed co-expression of HNF-1 $\alpha$. A similar pattern of expression was also found on E11.5. In a recent study, we generated beta cell-targeted transgenic mice with overexpression of a dominant negative human P291fsinsC-HNF-1 $\alpha$ mutant that suppressed endoge- 

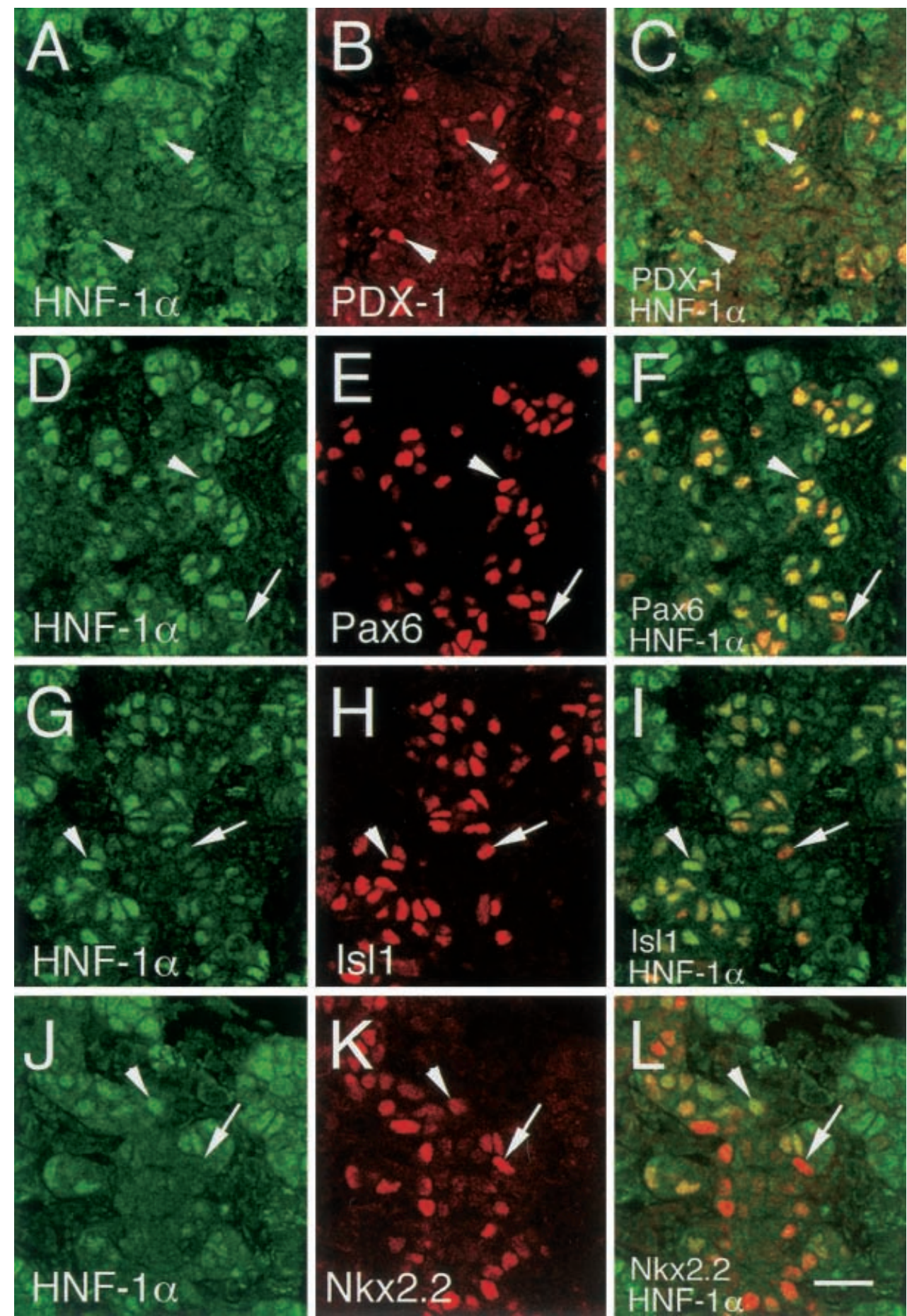

Fig. 6A-L. Double immunofluorescent staining of E15.5 mouse pancreas for transcription factors (PDX-1, Pax6, Isl1, and Nkx2.2) (labelled by Alexa 594, red) and HNF-1 $\alpha$ (Alexa 488 label, green). C, F, I, and $\mathbf{L}$ are superimposed images. Double positive cells show yellow color (arrowhead) and HNF-1 $\alpha$-negative cells show red color (arrow) $(\operatorname{Bar}=20 \mu \mathrm{m})$

nous HNF-1 $\alpha$ activity in pancreatic beta cells. Expression of Nkx2.2, Is11, Pax6 and PDX-1 appeared to be normal in the beta cells of transgenic mice (Fig. 7)
[19]. We also confirmed that PDX-1 expression remained unchanged in the beta cells of 2-week-old $H N F-1 \alpha(-/-)$ mice (Fig. 8). Earlier studies have placed Nkx2.2 upstream of Isl1 and Pax6 in the major pathway of beta-cell differentiation [25]. Taken together, these data suggest that HNF- $1 \alpha$ expression occurs after the expression of PDX-1, Nkx2.2, Is11, and Pax6 in developing beta-cells. However, PDX-1 expression was markedly decreased in $H N F-1 \alpha$ null mice after the onset of diabetes (Fig.8F), suggesting a secondary effect of hyperglycaemia. In fact, down- 


\section{Control}
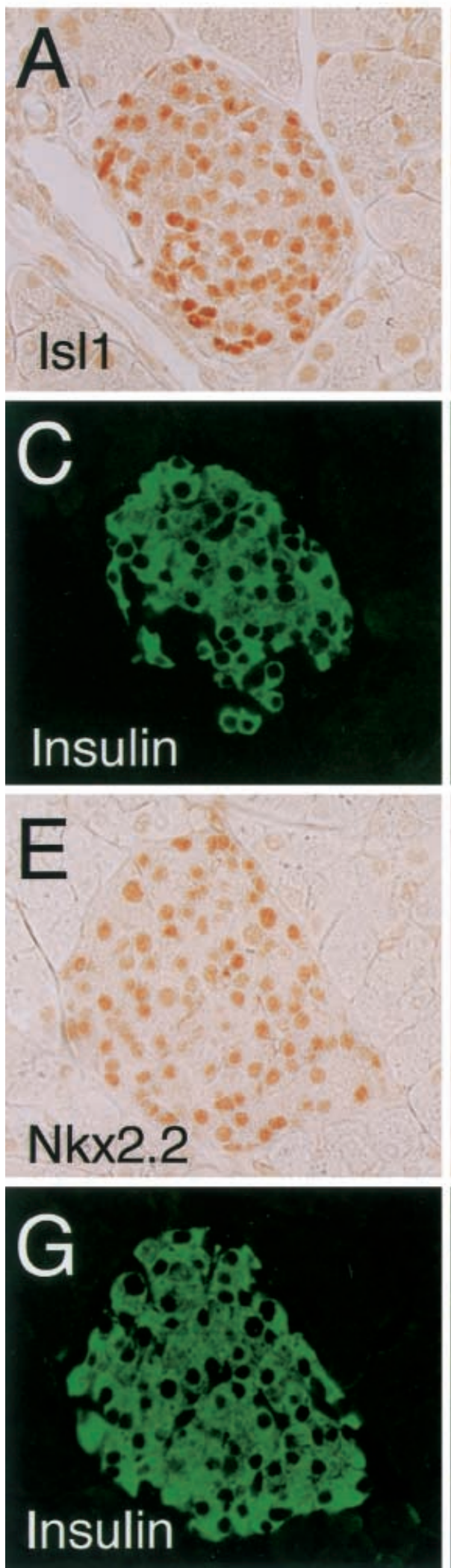

Fig. 7A-H. Expression of Is11 and Nkx2.2 in dominant negative HNF- $1 \alpha$ transgenic mice. Double immunostaining for transcription factors [Is11 (A, B) and Nkx2.2 (E, F)] (DAB label, brown) and insulin (Alexa 488 label, green) was done in

\section{Mutant}
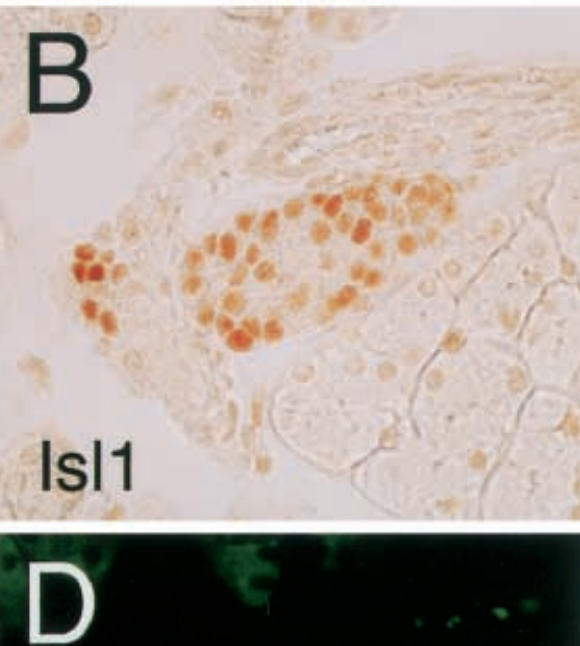

\section{Insulin}
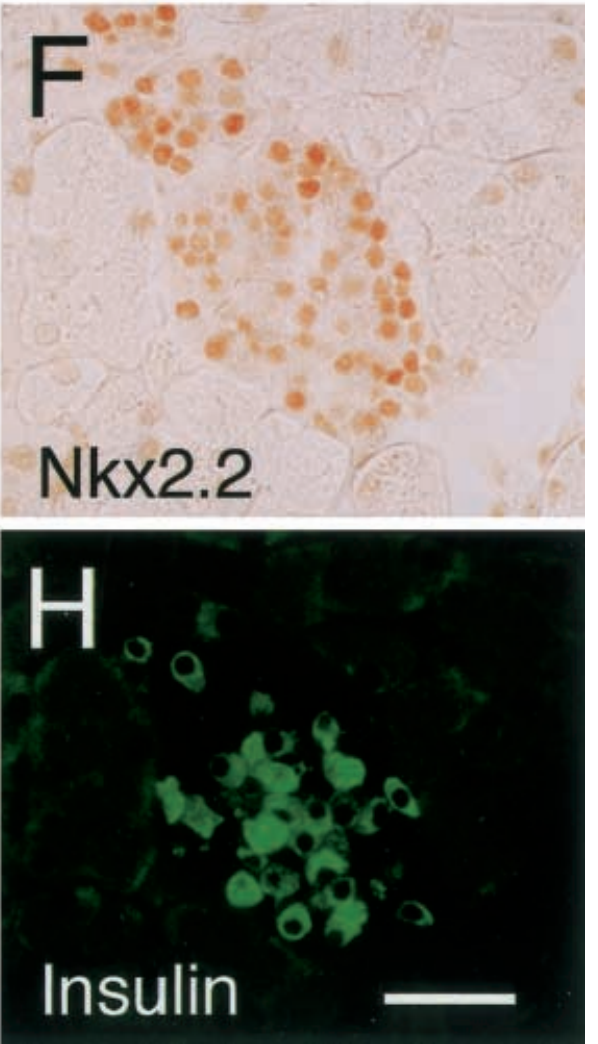

the pancreases of P291fsinsC-HNF-1 $\alpha$ transgenic $(\mathbf{B}, \mathbf{F})$ and control (A, E) mice. Expression of Is11 and $\mathrm{Nkx} 2.2$ by beta cells from transgenic mice was comparable to that by cells from control littermates $(\mathrm{Bar}=40 \mu \mathrm{m})$ 


\section{HNF-1 $\alpha(+/+)$}

\section{HNF-1 $1 \alpha(-/-)$}
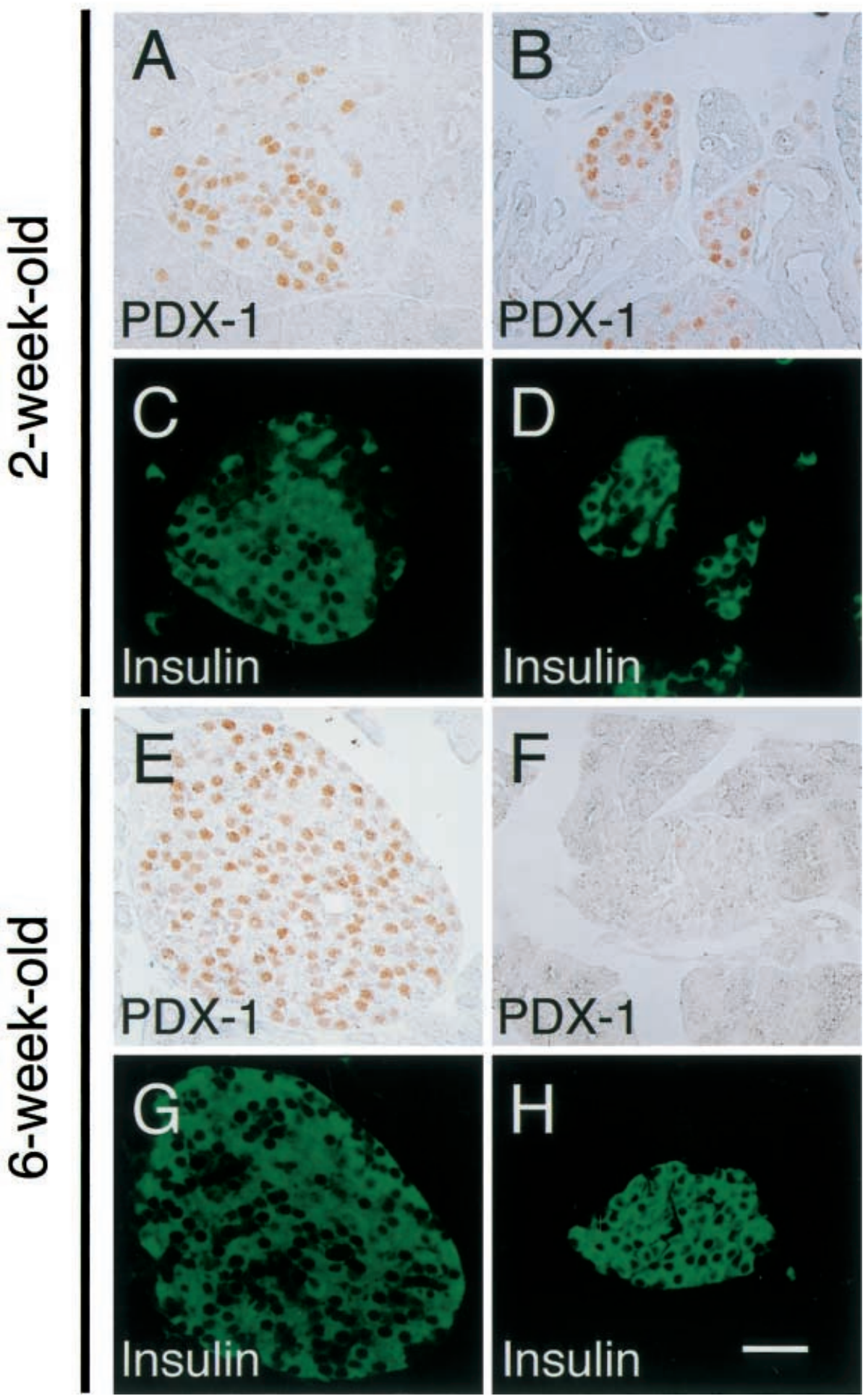

Fig. 8A-H. Expression of PDX-1 in $H N F-1 \alpha(-/-)$ mice. Double immunostaining for PDX-1 (A, B, E, F) (DAB label, brown) and insulin (Alexa 488 label, green) was done in the pancreas of $H N F-1 \alpha(-/-)$ mice $(\mathbf{B}, \mathbf{D}, \mathbf{F}, \mathbf{H})$ and their control littermates $(+/+)(\mathbf{A}, \mathbf{C}, \mathbf{E}, \mathbf{G})$. Expression of PDX-1 by beta cells from 2 -week-old pre-diabetic $H N F-1 \alpha(-/-)$ mice was comparable to that by control $(+/+)$ mice $(\mathbf{A}, \mathbf{B})$. In contrast, expression of PDX-1 was markedly reduced in 6-week-old mice after the onset of diabetes $(\mathbf{E}, \mathbf{F})$ regulation of PDX-1 by hyperglycaemia has been reported [38, 39].

\section{Discussion}

We have shown that HNF-1 $\alpha$ was expressed by endocrine cells as well as exocrine cells of the pancreas 
from the developmental stage. PDX-1 expression is limited to beta cells and delta cells in adult mice [40], whereas Nkx2.2 is expressed by alpha cells, beta cells, and PP cells, but not delta cells [37]. In contrast, HNF-1 $\alpha$ was expressed by all four kinds of endocrine cells, so it could regulate non-beta cells as well as beta cells in the pancreas. We previously reported that glucagon secretion was also impaired along with that of insulin in a MODY3 patient [41]. Isl1 and Pax6 are known to be expressed by all kinds of endocrine cells $[22,26]$ but exocrine cells do not express these transcription factors. Since HNF-1 $\alpha$ is strongly expressed by acinar cells, it might also be involved in the regulation of exocrine function. Serum concentrations of amylase and lipase were normal in a MODY3 patient [42] but the exocrine function of these patients were not examined in more detail.

HNF-1 $\alpha$ expression in the mouse pancreatic epithelium could first be clearly detected on embryonic day 10.5 , so its initial expression was delayed when compared with that of PDX-1 (E8.5) [34, 35, 43], Isl1 (E9.0) [22], and Pax6 (E9.0) [44], and Nkx2.2 (E9.5) [37]. Nkx2.2 is expressed by undifferentiated proendocrine cells [25]. In contrast, Isl1 and Pax6 are expressed by more differentiated endocrine cells [21, 25]. Our results suggest that HNF-1 $\alpha$ is expressed after the transcription factors PDX-1, Is11, Pax6, and Nkx2.2. Earlier studies have suggested that the sequence of the transcription factor expression in betacell development as follows: ngn $3^{{ }^{\text {nn}}}$-neuroDon-Isl1 on Pax6 ${ }^{\text {on }}$-ngn3 $3^{\text {off-PDX-1 }}$ high-insulin $^{\text {on }}$ [21]. Accordingly, we presume that HNF-1 $\alpha$ fits into this sequence as follows: ngn $3^{\text {on }}$-neuroD ${ }^{\text {on }}$-Isl $1{ }^{\text {on_Pax }}{ }^{\text {on }}{ }^{\text {-ngn }} 3^{\text {off-PDX- }}$ $1^{\text {high-HNF-1 }} \alpha^{\text {on }}$-insulin ${ }^{\text {on }}$. We and others have already suggested that HNF-1 $\alpha$ could be directly involved in transactivation of the insulin gene $[11,17,45]$ and the predicted position of HNF-1 $\alpha$ in the sequence would be compatible with this concept. In good accordance with the findings, PDX-1 expression is not reduced in beta cells of $H N F-1 \alpha$ mutant mice $([19,46]$ and this study) and dominant negative suppression of HNF-1 $\alpha$ activity in INS-1 cells does not affect the levels of PDX-1 and neuroD mRNA [17]. However, a previous study using RT-PCR suggested that PDX-1 expression was reduced in $H N F-1 \alpha(-/-)$ mice [47]. Since the number of beta cells is decreased in the islets of $H N F-1 \alpha$ null mice $[15,16]$, a reduced number of beta cells that express PDX-1 might be a possible explanation for the reduced expression of PDX-1 in the islets. Secondary down-regulation of PDX-1 by hyperglycaemia $[38,39]$ might also account for the discrepancy. It is not clear whether PDX-1 directly regulates the expression of the $H N F-1 \alpha$ gene transcription; therefore the regulation of HNF-1 $\alpha$ by other transcription factors should be examined. Recent studies have suggested that HNF- $1 \alpha$ regulation in the pancreas is more complex rather than a simple linear hierarchy $[47,48]$.
In summary, we clarified the profile of HNF-1 $\alpha$ expression in the adult and embryonic mouse pancreas. Since HNF-1 $\alpha$ expression was first detected during the development of the pancreas, it might have some functional role in this process. For example, the pancreatic islets of $H N F-1 \alpha$ null mice and transgenic mice with overexpression of dominant negative HNF-1 $\alpha$ were small and irregular in shape. E-cadherin-mediated cell adhesion is important for the proper organisation of the pancreatic islets [49] and HNF-1 $\alpha$ has been suggested to have a role in E-cadherin expression by islet cells [19]. The role of HNF- $1 \alpha$ in the beta cells during pancreatic development need to be clarified to understand better the molecular basis of HNF- $1 \alpha$ diabetes.

Acknowledgements. The monoclonal antibodies developed by Dr. A. Kawakami (anti-Pax6) and by Dr. T.M. Jessell (anti-Isl1 and anti-Nkx2.2) were obtained from the Developmental Studies Hybridoma Bank developed under the auspices of the National Institute of Child Health and Human Development (NICHD) and maintained by The University of Iowa, Department of Biological Sciences, Iowa City, IA 52242. We thank Dr. Y. Kajimoto for generously providing anti-PDX-1 antiserum. We are grateful to Dr. Q. Yang for assistance. This work was supported by grants from the Japanese Ministry of Education, Culture, Sports, Science and Technology (13204054, 13671190 and 12557089) and by a grant from the Research for the Future Program of The Japan Society for the Promotion of Science (97L00801).

\section{References}

1. Mendel DB, Crabtree GR (1991) HNF-1, a member of a novel class of dimerizing homeodomain proteins. J Biol Chem 266:677-680

2. Tronche F, Yaniv M (1992) HNF1, a homeoprotein member of the hepatic transcription regulatory network. Bioessays 14:579-587

3. Frain M, Swart G, Monaci P et al. (1989) The liver-specific transcription factor LF-B1 contains a highly diverged homeobox DNA binding domain. Cell 59:145-157

4. Baumhueter S, Mendel DB, Conley PB et al. (1990) HNF-1 shares three sequence motifs with the POU domain proteins and is identical to LF-B1 and APF. Genes Dev 4:372-379

5. Chouard T, Blumenfeld M, Bach I, Vandekerckhove J, Cereghini S, Yaniv M (1990) A distal dimerization domain is essential for DNA-binding by the atypical HNF1 homeodomain. Nucleic Acids Res 18:5853-5863

6. Pontoglio M, Barra J, Hadchouel H et al. (1996) Hepatocyte nuclear factor 1 inactivation results in hepatic dysfunction, phenylketonuria, and renal Fanconi syndrome. Cell 84:575-585

7. Yamagata K, Oda N, Kaisaki PJ et al. (1996) Mutations in the hepatocyte nuclear factor-1 $\alpha$ gene in maturity-onset diabetes of the young (MODY3). Nature 384:455-458

8. Byrne MM, Sturis J, Menzel S et al. (1996) Altered insulin secretory responses to glucose in diabetic and nondiabetic subjects with mutations in the diabetes susceptibility gene MODY3 on chromosome 12. Diabetes 45:1503-1510

9. Lehto M, Tuomi T, Mahtani MM et al. (1997) Characterization of the MODY3 diabetes. J Clin Invest 99:1-7 
10. Noguchi T, Yamada K, Yamagata K et al. (1991) Expression of liver type pyruvate kinase in insulinoma cells: involvement of LF-B1 (HNF1). Biochem Biophys Res Commun 181:259-264

11. Emens LA, Landers DW, Moss LG (1992) Hepatocyte nuclear factor $1 \alpha$ is expressed in a hamster insulinoma line and transactivates the rat insulin I gene. Proc Natl Acad Sci USA 89:7300-7304

12. Sander M, German MS (1997) The beta cell transcription factors and development of the pancreas. J Mol Med 75:327-340

13. St-Onge L, Wehr R, Gruss P (1990) Pancreas development and diabetes. Curr Opin Genet Dev 9:295-300

14. Edlund H (2001) Developmental biology of the pancreas. Diabetes 50:S5-S9

15. Pontoglio M, Sreenan S, Roe M et al. (1998) Defective insulin secretion in hepatocyte nuclear factor $1 \alpha$-deficient mice. J Clin Invest 101:2215-2222

16. Lee YH, Sauer B, Gonzalez FJ (1998) Laron dwarfism and non-insulin-dependent diabetes mellitus in the Hnf-1 $\alpha$ knockout mouse. Mol Cell Biol 18:3059-3068

17. Wang H, Maechler P, Hagenfeldt KA, Wollheim CB (1998) Dominant-negative suppression of $\mathrm{HNF}-1 \alpha$ function results in defective insulin gene transcription and impaired metabolism-secretion coupling in a pancreatic beta-cell line. EMBO J 17:6701-6713

18. Hagenfeldt KA, Herrera PL, Wang H, Gjinovci A, Ishihara H, Wollheim CB (2001) Beta-cell-targeted expression of a dominant-negative hepatocyte nuclear factor- $1 \alpha$ induces a maturity-onset diabetes of the young (MODY)3-like phenotype in transgenic mice. Endocrinology 142:53115320

19. Yamagata K, Nammo T, Moriwaki M et al. (2002) Overexpression of dominant-negative HNF-1 $\alpha$ in pancreatic beta cells causes abnormal islet architecture with decreased expression of E-cadherin, reduced beta-cell proliferation and diabetes. Diabetes 51:114-123

20. Sander M, Sussel L, Conners J et al. (2000) Homeobox gene Nkx6.1 lies downstream of Nkx2.2 in the major pathway of beta-cell formation in the pancreas. Development 127:5533-5540

21. Jensen J, Heller RS, Funder-Nielsen T et al. (2000) Independent development of pancreatic alpha- and beta cells from neurogenin3-expressing precursors: a role for the notch pathway in repression of premature differentiation. Diabetes 49:163-176

22. Ahlgren U, Pfaff SL, Jessell TM, Edlund T, Edlund H (1997) Independent requirement for ISL1 in formation of pancreatic mesenchyme and islet cells. Nature 385:257260

23. Apelqvist A, Li H, Sommer L et al. (1999) Notch signalling controls pancreatic cell differentiation. Nature 400: $877-881$

24. Gradwohl G, Dierich A, LeMeur M, Guillemot F (2000) Neurogenin 3 is required for the development of the four endocrine cell lineages of the pancreas. Proc Natl Acad Sci USA 97:1607-1611

25. Schwitzgebel VM, Scheel DW, Conners JR et al. (2000) Expression of neurogenin3 reveals an islet cell precursor population in the pancreas. Development 127:3533-3542

26. St-Onge L, Sosa-Pineda B, Chowdhury K, Mansouri A, Gruss P (1997) Pax6 is required for differentiation of glucagon-producing alpha cells in mouse pancreas. Nature 387:406-409

27. Yamagata K, Yang Q, Yamamoto K et al. (1998) Mutation P291fsinsC in the transcription factor hepatocyte nuclear factor- $1 \alpha$ is dominant negative. Diabetes 47:1231-1235
28. Blobel G, Potter VR (1966) Nuclei from rat liver: isolation method that combines purity with high yield. Science: 154:1662-1665

29. Waguri M, Yamamoto K, Miyagawa JI et al. (1997) Demonstration of two different processes of beta-cell regeneration in a new diabetic mouse model induced by selective perfusion of alloxan. Diabetes 46:1281-1290

30. Blumenfeld M, Maury M, Chouard T, Yaniv M, Condamine H (1991) Hepatic nuclear factor 1 (HNF1) shows a wider distribution than products of its known target genes in developing mouse. Development 113:589-599

31. Cereghini S, Ott MO, Power S, Maury M (1992) Expression patterns of vHNF1 and HNF1 homeoproteins in early postimplantation embryos suggest distinct and sequential developmental roles. Development 116:783-797

32. Pictet R, Rutter WJ (1972) Development of the embryonic endocrine pancreas. In: Steiner DF, Freinkel N (eds) Handbook of Physiology. Vol 1. American Physiological Society, Washington DC, pp 25-66

33. Teitelman G, Alpert S, Polak JM, Martinez A, Hanahan D (1993) Precursor cells of mouse endocrine pancreas coexpress insulin, glucagon and the neuronal proteins tyrosine hydroxylase and neuropeptide Y, but not pancreatic polypeptide. Development 118:1031-1039

34. Ohlsson H, Karlsson K, Edlund T (1993) IPF1, a homeodomain-containing transactivator of the insulin gene. EMBO J 12:4251-4259

35. Jonsson J, Carlsson L, Edlund T, Edlund H (1994) Insulinpromoter-factor 1 is required for pancreas development in mice. Nature 371:606-609

36. Karlsson O, Thor S, Norberg T, Ohlsson H, Edlund T (1990) Insulin gene enhancer binding protein Isl-1 is a member of a novel class of proteins containing both a homeo- and a Cys-His domain. Nature 344:879-882

37. Sussel L, Kalamaras J, Hartigan-O'Connor DJ et al. (1998) Mice lacking the homeodomain transcription factor $\mathrm{Nkx} 2.2$ have diabetes due to arrested differentiation of pancreatic beta cells. Development 125:2213-2221

38. Seufert J, Weir GC, Habener JF (1998) Differential expression of the insulin gene transcriptional repressor CCAAT/enhancer-binding protein beta and transactivator islet duodenum homeobox-1 in rat pancreatic beta cells during the development of diabetes mellitus. J Clin Invest. 101: 2528-2539

39. Jonas JC, Sharma A, Haenkamp W et al. (1999) Chronic hyperglycemia triggers loss of pancreatic beta cell differentiation in an animal model of diabetes. J Biol Chem 274:14112-14121

40. Guz Y, Montminy MR, Stein R et al. (1995) Expression of murine STF-1, a putative insulin gene transcription factor, in beta cells of pancreas, duodenal epithelium and pancreatic exocrine and endocrine progenitors during ontogeny. Development 121:11-18

41. Yoshiuchi I, Yamagata K, Yang Q et al. (1999) Three new mutations in the hepatocyte nuclear factor- $1 \alpha$ gene in Japanese subjects with diabetes mellitus: clinical features and functional characterization. Diabetologia 42:621-626

42. Yoshiuchi I, Yamagata K, Yoshimoto M et al. (2001) Analysis of a non-functional HNF-1alpha (TCF1) mutation in Japanese subjects with familial type 1 diabetes. Hum Mutat 18:345-351

43. Ahlgren U, Jonsson J, Edlund H (1996) The morphogenesis of the pancreatic mesenchyme is uncoupled from that of the pancreatic epithelium in IPF1/PDX1-deficient mice. Development 122:1409-1416

44. Sander M, Neubuser A, Kalamaras J, Ee HC, Martin GR, German MS (1997) Genetic analysis reveals that PAX6 is 
required for normal transcription of pancreatic hormone genes and islet development. Genes Dev 11:1662-1673

45. Okita K, Yang Q, Yamagata K et al. (1999) Human insulin gene is a target gene of hepatocyte nuclear factor- $1 \alpha$ $(\mathrm{HNF}-1 \alpha)$ and HNF-1 $\beta$. Biochem Biophys Res Commun 263:566-569

46. Parrizas M, Maestro MA, Boj SF (2001) Hepatic nuclear factor 1-alpha directs nucleosomal hyperacetylation to its tissue-specific transcriptional targets. Mol Cell Biol $21: 3234-3243$
47. Shih DQ, Screenan S, Munoz KN et al. (2001) Loss of HNF- $1 \alpha$ function in mice leads to abnormal expression of genes involved in pancreatic islet development and metabolism. Diabetes 50:2472-2480

48. Boj SF, Parrizas M, Maestro MA, Ferrer J (2001) A transcription factor regulatory circuit in differentiated pancreatic cells. Proc Natl Acad Sci USA 98:14481-14486

49. Dahl U, Sjodin A, Semb H (1996) Cadherins regulate aggregation of pancreatic $\beta$-cells in vivo. Development 122:2895-2902 